\title{
Record of Thermocyclops tenuis (Marsh, 1910) (Copepoda: Crustacea) in the Pantanal (Mato Grosso do Sul - Brazil)
}

\author{
Silva, WM.* \\ Departamento de Ciencias Ambientais, Campus do Pantanal (CPAN), \\ Universidade Federal de Mato Grosso do Sul - UFMS, \\ Av. Rio Branco, 1270, CEP 79304-020, Corumbá, MS, Brazil \\ *e-mail: wmsilvax@ig.com.br
}

Received November 24, 2008 - Accepted March 24, 2008 - Distributed November 30, 2009

(With 2 figures)

The aim of this note is to record the occurrence of the copepod Cyclopoida Thermocyclops tenuis in the Pantanal region, Central West of Brazil. The sampling was carried out in September, 2008, in a small artificial pond with an area of $22 \mathrm{~m}^{2}$ and $0.5 \mathrm{~m}$ deep, located in the city of Corumbá, MS, at $19^{\circ} 00^{\prime \prime} 02^{\prime} \mathrm{S}$ and $57^{\circ} 37^{\prime \prime} 50$ ' W. The material was concentrated in a plankton net with $68 \mu \mathrm{m}$ mesh size and fixed in a $4 \%$ formaldehyde solution. The organisms were identified in an optical microscope with image capture and drawings accomplished with Turbo Cad 6.5 software.

Thermocyclops tenuis was found in the sample making up the main population of Cyclopoida (97\%) together with Mesocyclops longisetus (Thiébaud, 1914).

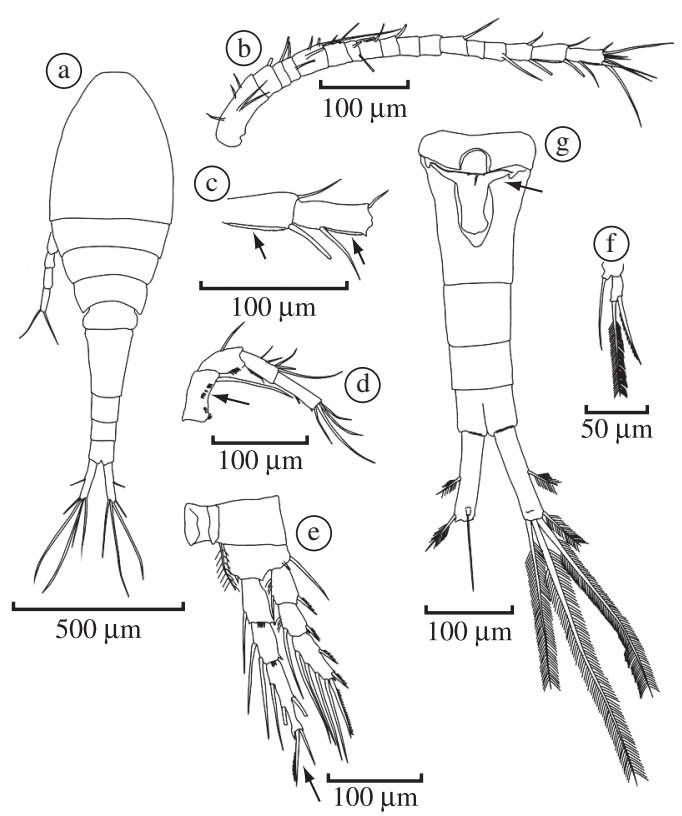

Figure 1. Thermocyclops tenuis female. a) General aspect; b) Antennule; c) Detail of the $16^{\text {th }}$ and $17^{\text {th }}$ antennule segments (setae: hyaline membrane); d) Antenna (setae: spine rows in the basipodite); e) Leg 4 (setae: apical spines of the endopodite); f) Leg 5; and g) Urosome (setae: seminal receptacle).

\section{Characteristics of the species}

The mean body size from $T$. tenuis female (Figure 1a) was $1,124 \mu \mathrm{m}(\mathrm{n}=10, \mathrm{SD}=61.72 \mu \mathrm{m})$, deposited in the USP Museum (MZUSP 19390). The appendages and the morphological characteristics used for differential diagnosis were: smooth hyaline membrane in the $16^{\text {th }}$ and $17^{\text {th }}$ segments (Figure 1c) of the antennule (Figure 1b); patterns of spine rows in the basipodite of antenna (Figure 1d); relationship about size of the apical spines in the $3^{\text {rd }}$ segment of the endopodite of the leg 4 (Figure 1e); leg 5 (Figure 1f); shape of seminal receptacle and furca proportion about 4.4 as long as wide (Figure $1 \mathrm{~g}$ ). These charac-

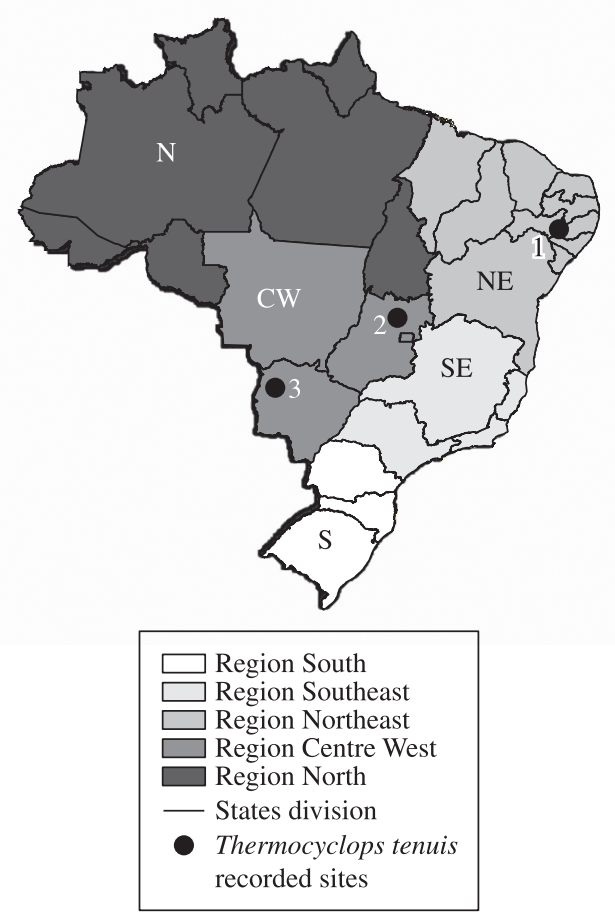

Figure 2. Brazilian territory and its political division, States and Regions: $\mathrm{N}=$ North; $\mathrm{NE}=$ Northeast $\mathrm{CW}=$ Centre west; SE = Southeast; $\mathrm{S}=$ South; and the sites of the T. tenuis records: 1) Pernambuco State, records in 1936 and 1938; 2) Goiás State, records in 1980 and 1983; 3) Mato Grosso do Sul State, records in 2008. 
teristics are in agreement with the taxonomical diagnosis made by Kiefer (1936), Coker (1943) and Smith and Fernando (1980).

\section{Geographical distribution}

The species was recorded for the first time in the northeast region of Brazil (Pernambuco State) (Figure 2) by Kiefer, (1936) and furthermore by Schubart (1938) in the same region. Reid (1989) recorded the species in the Central-West region of Brazil (Goiás State) and the present paper shows the occurrence of this species in the same region, but in Mato Grosso do Sul State, Pantanal.

The distribution of this species in the Brazilian territory seems to be restricted in the Northern and Central West region until $20^{\circ} \mathrm{S}$. The species has not been registered at the present day at higher latitudes despite the extensive studies carried out by Silva and MatsumuraTundisi (2005) in water bodies of São Paulo State (Southeastern part of Brazil- between $19^{\circ} 47^{\prime} \mathrm{S}$ and $25^{\circ} 13^{\prime} \mathrm{S}$.

\section{References}

COKER, RE., 1973. Mesocyclops edax (S.A. Forbes), M. leuckarti (Claus) and related species in America. Elisha Mitchell Scientific Society, vol. 59, no. 2, p. 181-200.

KIEFER, F., 1936. Brasilianische ruderfußkrebse (Crustacea Copepoda), gesammet von Herrn Dr. Otto Schubart. III. Mitteilung, Zoologischer Anzeiger, vol. 114, p. 320-322.

REID, JW., 1989. The distributions of species of the genus Thermocyclops (Copepoda, Cyclopoida) in the western hemisphere, with a description of $T$. parvus, new species. Hydrobiologia, vol. 175, no. 2, p. 149-174.

SCHUBART, O., 1938. Considerações sobre as investigações nas águas de Pernambuco. Arquivos Instituto de Pesquisas Agronômicas de Pernambuco, vol. 1, no. 1, p. 26-57.

SILVA, WM. and MATSUMURA-TUNDISI, T., 2005. Taxonomy, ecology and geographic distribution of the species of the genus Thermocyclops Kiefer, 1927 (Copepoda, Cyclopoida) in São Paulo State, Brazil, with description of a new species. Revista Brasileira de Biologia = Brazilian Journal of Biology, vol. 65, no. 3, p. 533-540.

SMITH, KE. and FERNANDO, CH., 1980. Guia para los Copépodos (Calanoida y Cyclopoida) de las aguas dulces de Cuba. La Habana: Editorial Academia. 27 p. 